\title{
Konsep kemiskinan (subjektif) dalam benak masyarakat Indonesia: konstruk dan indikatornya
}

\author{
Tri Rejeki Andayani*, Hardjono, \& Fadjri Kirana Anggarani \\ Program Studi Psikologi, Fakultas Kedokteran, Universitas Sebelas Maret, Surakarta
}

\begin{abstract}
Abstrak
Penelitian ini bertujuan untuk mengembangkan konsep kemiskinan subjektifdan menguji indikatorindikatornya. Untuk itu, penelitian dengan pendekatan Psikologi Indigenous ini dilakukan melalui dua tahap studi. Total sampel penelitian ini sebanyak 283 responden, terdiri dari 148 responden dalam Studi 1 dan 135 responden dalam Studi 2. Pengumpulan data Studi 1 dengan kuesioner pertanyaan terbuka dan analisis data menggunakan teknik analisis isi, sedangkan pengumpulan data Studi 2 dengan Skala Kemiskinan Subjektif yang disusun berdasarkan temuan Studi 1. Teknik Analisis Faktor Eksploratori dilakukan untuk menemukan indikator-indikator dari dimensi kemiskinan subjektif. Hasil Studi 1 menunjukkan bahwa kemiskinan subjektif pada mahasiswa merepresentasikan adanya perasaan dan/atau pemikiran yang menilai dirinya berada dalam keterbatasan material, spiritual, intelektual, emosional, dan relasional. Hasil Studi 2 membuktikan indikator perilaku dalam aspek kemiskinan subjektif yang dihasilkan pada Studi 1 sebel umnya terbukti mampu menjelaskan konstruk kemiskinan subjektif.
\end{abstract}

Kata kunci: kemiskinan subjektif, indikator kemiskinan

\begin{abstract}
The aim of this study was to develop a concept of subjective poverty and to validate its indicator. An indigenous psychological approach was used in this research through two stages of the study. The study population was college students and samples were selected by accidental sampling. A total of samples were 283 respondents consisted of 148 college students as sample in Study 1 and 135 college students sample of Study 2. Data collection in Study 1 was administered by using open-ended questionnaire and we used content analysis technique to analyze the data. For Study 2, a newly constructed Subjective Poverty Scale was administered. The items of this newly developed scale were derived from a previous qualitative study (the findings of Study 1). Subjective poverty indicators were assessed with exploratory factor analysis. The result of Study 1 showed that subjective poverty for college student in Indonesia was represented by the feeling and thought of lacking in material, spiritual, intellectual, emotional, and relational aspects. The result of Study 2 proved that the indicators in each aspects of subjective poverty were able to explain the construct of subjective poverty.
\end{abstract}

Keywords: subjective poverty, indicator of poverty

\section{Pendahuluan}

Pengentasan kemiskinan dalam perspektif luas ternyata tidak hanya menyangkut pengentasan dari tingkat ketidakmampuan atau ketidakberdayaan dari segi ekonomi atau fisik saja. Kemiskinan juga perlu dipahami dari aspek-aspek yang lain, termasuk dari aspek psikologis, yakni tentang seberapa cukup seseorang memersepsikan hidupnya, atau sebaliknya seberapa kurang seseorang dalam hal pemenuhan kebutuhannya. Inilah yang memunculkan istilah miskin secara subjektif (Burtless \& Smeeding, 2001; Goedemé \& Rottiers, 2011; Niemietz, 2011). Istilah ini memberi konsep lebih luas terhadap arti miskin, dibandingkan hanya sekedar miskin karena kurangnya pendapatan (income poverty), sehingga ini diinterpretasikan sebagai lack of happiness terhadap domain-domain seperti pendapatan, kesehatan, rekreasi, dan lingkungan sosial (Van Praag \& Ferreri-Carbonell, 2005).

Namun pada perkembangannya, riset-riset mengenai kemiskinan mayoritas tetap saja masih mengacu pada soal keterbatasan pendapatan atau finansial yang hal ini merujuk lagi pada domain ekonomi. Tidak heran jika kemiskinan subjektif pun masih diartikan sebagai penilaian terhadap diri 
sendiri sebagai "miskin" atau "sangat miskin" yang berkaitan dengan evaluasi subjektif mengenai keadaan finansial individu (Marks, 2005; Buttler, 2013). Berdasarkan rendahnya pendapatan tersebut maka muncul dua konsep kemiskinan, yakni kemiskinan absolut dan kemiskinan relatif. Kemiskinan absolut didasarkan pada pendapatan sebenarnya yang diperoleh individu dimana apabila berada di bawah garis ukur tertentu maka yang bersangkutan dapat dikategorikan miskin (Bergh \& Nilsson, 2014). Sementara kemiskinan relatif didasarkan pada perbandingan pendapatan individu dengan atas pendapatan lingkungan sekitar sehingga kemiskinan ini bersifat relatif atau relative income poverty (Burtless \& Smeeding, 2001; Haisley, Mostafa, \& Loewenstein, 2008).

Demikian pula dengan perkembangan riset mengenai kemiskinan yang dilakukan para peneliti di Indonesia. Seperti survei yang dilakukan oleh Badan Pusat Statistik (BPS), Survei Sosial Ekonomi Nasional (SUSENAS), dan Sensus Penduduk, serta Potensi Desa (PODES). Ada pula yang mengukur kemiskinan dengan menggunakan indikator tingkat kesejahteraan keluarga seperti yang dilakukan oleh Badan Koordinasi Keluarga Berencana Nasional (BKKBN).

Penelitian yang bertujuan untuk mengembangkan konsep dan pengukuran kemiskinan subjektif di Indonesia yang tidak hanya mengacu pada keterbatasan dari segi finansial atau sudut pandang ekonomi saja sesungguhnya telah dimulai oleh beberapa peneliti (Cahyat, 2004; Markum, 2009; Susilowati, 2016; Fatony, 2011; Sumarto, 2013). Bila dicermati dari beberapa studi tersebut, telah ada usaha menyusun konsep dan tolak ukur tentang kemiskinan secara lebih luas, namun belum satupun dari penelitian tersebut yang melakukan pengujian indikator perilaku dari kemiskinan tersebut. Oleh karena itu, dalam penelitian kali ini tidak hanya bertujuan untuk menyusun konsep dan menemukan aspek-aspek dari kemiskinan subjektif, khususnya dalam konteks kemiskinan pada mahasiswa di Indonesia, tetapi juga akan menguji indikator-indikator pada tiap aspeknya.

Untuk mencapai tujuan tersebut, penelitian ini menggunakan pendekatan psikologi ulayat atau indigenous psychology. Pendekatan ini menekankan metode induktif atau menggunakan model pendekatan secara bottom-up agar peran konteks budaya yang sarat makna terhadap perilaku dan proses mental manusia tidak diabaikan dalam penelitian (Hwang, 2010). Dari segi metodologi, meskipun penelitian dengan pendekatan ini tidak menghalangi pemakaian metode tertentu, namun ditekankan oleh Kim, Yang, dan Hwang (2010) bahwa penelitian dengan pendekatan psikologi indigenous sebaiknya dilakukan dengan rancangan multiplemethod agar dapat m emberikan pemahaman yang lebih komprehensif tentang fenomena psikologis yang dikaji. Oleh karena itu, penelitian ini akan menggunakan rancangan eksploratori-eksplanatori berurutan, dimulai dari studi kualitatif eksplorasi sebagai Studi 1 untuk menggali aspek-aspek penyusun konstruk kemiskinan subjektif di Indonesia dan mengidentifikasi indikator-indikatornya. Dari hasil temuan tersebut, maka pada studi selanjutnya sebagai Studi 2 dengan pendekatan kuantitatif eksplanatif akan menguji indikator-indikator kemiskinan subjektif pada tiap aspek yang telah dikonstruksi dari temuan Studi 1 sebelumnya tersebut.

\section{Studi 1}

\section{Metode Penelitian}

Populasi penelitian ini adalah mahasiswa di Indonesia, sampel dipilih dengan teknik incidental sampling. Jumlah sampel awal dalam Studi 1 sebanyak 241 partisipan, tetapi yang dapat digunakan dalam penelitian eksploratif ini sebanyak 148 partisipan $(M=20,57 ; S D=2,679)$. Ini dikarenakan dari 241 tersebut, 93 partisipan mengaku tidak pernah merasa miskin.

Pengumpulan data dalam Studi 1 dilakukan dengan kuesioner pertanyaan terbuka yang disampaikan melalui Google Form. Kuesioner terdiri dari dua pertanyaan sebagai berikut: (1) "Apakah Anda masih merasa miskin?, (2) Jika ya, mengapa?.

Data kualitatif dianalisis dengan teknik analisis isi karena bertujuan untuk menemukan tema-tema utama yang merepresentasikan kemiskin-an dari sudut pandang partisipan. Proses koding ini melibatkan tiga mahasiswa Psikologi yang telah lulus mata kuliah Metodologi Penelitian Kualitatif. Untuk inter-rater reliability sesungguhnya dapat melibatkan dua pihak saja (Gwet, 2014), tetapi kehadiran orang ketiga pada saat tertentu dibutuhkan jika ada perbedaan pendapat saat menentukan kategorisasi.

\section{Hasil Penelitian}

Berdasarkan deskripsi responden yang mengatakan bahwa dirinya masih merasa miskin, mayoritas responden mengemukakan lebih dari satu alasan saat mendeskripsikannya sehingga analisis isi bersifat multiple response analysis. Berikut ini beberapa contoh respon yang menunjukkan adanya kemajemukan alasan responden dan kata yang digarisbawahi adalah kata kunci yang merepresentasikan berbagai aspek kemiskinan subjektif.

Saat uang habis, saat ilmu tidak bertambah, saat teman tidak bertambah saat tidak bisa bermanfaat untukorang lain (R. 223/P); Disaat tidak memiliki uang dan di saat tidakmendapat kasih sayang (R. 57/P).

Selain itu, ada juga respon yang bersifat tunggal, seperti yang dikemukakan responden ini:

Saya tidak memiliki penghasilan sama sekali dan sepenuhnya harus hidup dengan bantuan orang tua (R. 55/L); Kurang memiliki prestasi (R.48/P). 
Tabel 1. Hasil Akhir Kategorisasi Tema

\begin{tabular}{|c|c|c|c|c|c|c|}
\hline \multirow[t]{2}{*}{ Kategorisasi (tema utama, subtema) } & \multicolumn{2}{|c|}{ Laki-laki } & \multicolumn{2}{|c|}{ Perempuan } & \multicolumn{2}{|c|}{ Total } \\
\hline & Jumlah & $\%$ & Jumlah & $\%$ & Jumlah & $\%$ \\
\hline 1. Material & 27 & 15,52 & 98 & 56,32 & 125 & 71,84 \\
\hline a. Keterbatasan uang & 21 & 12,07 & 82 & 47,13 & 103 & 59,20 \\
\hline b. Sulitnya memenuhi kebutuhan & 4 & 2,30 & 13 & 7,47 & 17 & 9,77 \\
\hline c. Tidak punya rumah/kendaraan pribadi & 2 & 1,15 & 2 & 1,15 & 4 & 2,30 \\
\hline d. Sakit dan tidak ada jaminan kesehatan & 0 & 0,00 & 1 & 0,57 & 1 & 0,57 \\
\hline 2. Spiritual & 3 & 1,72 & 12 & 6,90 & 15 & 8,62 \\
\hline a. Belum bermanfaat untuk orang lain & 1 & 0,57 & 7 & 4,02 & 8 & 4,60 \\
\hline b. Merasa jauh dari Tuhan. & 2 & 1,15 & 3 & 1,72 & 5 & 2,87 \\
\hline c. Kurang mengerti/memahami ilmu agama & 0 & 0,00 & 2 & 1,15 & 2 & 1,15 \\
\hline 3. Intelektual & 1 & 0,57 & 13 & 7,47 & 14 & 8,05 \\
\hline a. $\quad$ Kurang pengalaman \& prestasi & 1 & 0,57 & 6 & 3,45 & 7 & 4,02 \\
\hline b. Kurang pengetahuan \& kompetensi & 0 & 0,00 & 7 & 4,02 & 7 & 4,02 \\
\hline 4. Relasional & 0 & 0,00 & 9 & 5,17 & 9 & 5,17 \\
\hline a. Sedikit teman & 0 & 0,00 & 6 & 3,45 & 6 & 3,45 \\
\hline b. Tidak memiliki saudara & 0 & 0,00 & 3 & 1,72 & 3 & 1,72 \\
\hline 5. Emosional & 2 & 1,15 & 9 & 5,17 & 11 & 6,32 \\
\hline a. iri pada keberuntungan orang lain & 2 & 1,15 & 5 & 2,87 & 7 & 4,02 \\
\hline b. Kurang kasih sayang & 0 & 0,00 & 4 & 2,30 & 4 & 2,30 \\
\hline Jumlah & 33 & 18,97 & 141 & 81,03 & 174 & 100,00 \\
\hline
\end{tabular}

Berdasarkan proses open coding pada berbagai alasan yang dikemukakan 148 responden yang mengaku masih merasa miskin diperoleh 174 kata kunci yang dapat dimaknai dan kata kunci yang bermakna sama lalu dikategorikan dalam subtema yang sama dan hasil akhir dari proses axial coding diperoleh tiga belas subtema. Tema-tema tersebut lalu dikategorikan lagi melalui proses selective coding dan diperoleh lima tema utama yang merepresentasikan aspek-aspek kemiskinan subjektif. Tabel 1 menyajikan persentase tiap respon dalam setiap kategori tema.

Dari hasil studi eksplorasi tersebut tampak bahwa kemiskinan subjektif pada mahasiswa dikonseptualisasikan sebagai satu perasaan dan/atau pemikiran bahwa dirinya berada dalam keterbatasan tidak hanya dari aspek material saja, tetapi juga aspek spiritual, intel ektual, emosional, dan relasional.

\section{Diskusi}

Tidak dimungkiri bahwa kemiskinan yang direpresentasikan dari segi keterbatasan material terutama dari segi rendahnya kemampuan finansial (uang) masih mendominasi dalam temuan ini. Hal ini sejalan dengan beberapa konsep kemiskinan yang dikemukakan oleh beberapa lembaga seperti Bank Dunia (World Bank) yang menentukan kemiskinan secara absolut dari tingkat penghasilan keluarga dalam ukuran dollar (US\$). Jika masyarakat atau keluarga memiliki pendapatan atau penghasilan kurang dari US\$2 per harinya (less than USS\$ 1 - US\$ 2 per day) maka masuk dalam kategori miskin. Demikian pula BPS yang menghitung jumlah dan persentase penduduk miskin (head count index) yaitu penduduk yang hidup dibawah garis kemiskinan berdasarkan data hasil Susenas. Garis kemiskinan ini merupakan dasar penghitungan jumlah penduduk miskin dihitung dengan menggunakan pendekatan kebutuhan dasar (basic needs approach) yaitu besarnya rupiah yang dibutuhkan untuk dapat memenuhi kebutuhan dasar minimum makanan dan non makanan.

Munculnya deprivasi dari segi kesehatan dan rendahnya pengetahuan (aspek intelektual) yang dirasakan oleh responden dalam penelitian ini saat merepresentasikan kemiskinan sejalan dengan temuan Tsui (2002) yang menemukan bahwa kesehatan dan pendidikan menjadi kebutuhan dasar manusia yang perlu dilibatkan dalam pengukuran kemiskinan. Pentingnya mempertimbangkan aspek pendidikan atau intelektualitas manusia juga ditekankan oleh Bank Dunia (World Bank) bahwa pembangunan manusia tidak hanya diutamakan pada aspek ekonomi, tetapi juga perlu meng-utamakan aspek pendidikan secara universal bagi kepentingan diri orang miskin untuk menunjang peningkatan kehidupan sosial ekonominya. 
Demikian pula kemiskinan dari segi spiritual yang ditandai dengan perasaan responden yang masih kurang menguasai ilmu agama, merasa jauh dari Tuhan, dan masih merasa belum bermanfaat bagi orang lain muncul sebagai representasi kemiskinan responden dalam penelitian ini. Aspek spiritual jika terpenuhi tentulah menjadi modal sosial yang menunjang pembangunan sosial sebagai upaya dari pengentasan kemiskinan. Seperti yang diungkapkan Adi (2008) bahwa setiap manusia memiliki dorongan dalam diri yang bersumber dari kekuatan transedental di luar diri manusia. Dorongan ini membawa manusia tidak semata-mata berorientasi pada materi atau duniawi, tetapi juga rohani atau kehidupan yang lebih hakiki. Modal spiritual tersebut memiliki peran dalam proses pembangunan sosial, pengembangan dan pemberdayaan masyarakat.

Kurang kasih sayang dan mudah merasa iri saat melihat keadaan orang lain yang menurut responden dinilai lebih kaya dan beruntung menjadi indikator dari kemiskinan secara emosional yang dirasakan oleh responden dalam penelitian ini. Halini sejalan dengan Faturochman (2005), Feather (2002), serta Guimond dan Dambrun (2002) yang akan dibahas lebih lanjut dalam pembahasan secara keseluruhan dari penelitian ini.

Kemiskinan secara relasional yang muncul dalam penelitian ini menguatkan bahwa masyarakat Indonesia pada umumnya masih bersifat kolektif. Tidak heran jika minimnya jumlah saudara kandung yang dimiliki responden menjadi salah satu indikator yang muncul dalam penelitian ini. Selain itu, kemiskinan dari segi relasional juga diindikasikan dari perasaan atau pikiran responden yang merasa kurang berhasil dalam menjalin relasi interpersonal dengan orang sekitarnya.

Setelah konsep kemiskinan subjektif sudah dapat dikonstruksikan dengan jelas dari hasil Studi 1 tersebut di atas, maka langkah berikutnya adalah menguji kesesuaian antara indikator dengan aspekaspek tersebut. Aspek pertama dari kemiskinan subjektif, yakni material diduga memiliki empat indikator perilaku, yakni: (1) masih merasa jumlah uangyang dimiliki sangat terbatas; (2) merasa miskin karena belum memiliki rumah sendiri, barang elektronik, dan kendaraan pribadi; (3) belum memiliki penghasilan sendiri; (4) tidak memiliki jaminan asuransi kesehatan. Aspek spiritual memiliki tiga indikator perilaku, yakni: (1) merasa miskin karena kurang mengerti dan memahami ilmu agama; (2) merasa jauh dari Tuhan; (3) Belum sepenuhnya bermanfaat untuk orang lain. Aspek intelektual memiliki dua indikator perilaku, yakni: (1) merasa miskin karena kurang memiliki ilmu pengetahuan yang cukup; (2) merasa kurang pengalaman dan prestasi. Aspek emosional memiliki dua indikator yakni: (1) kurangnya kasih sayang dari orang-orang disekitarnya; (2) merasa iri dengan orang lain yang dinilai lebih kaya dan beruntung. Aspek kemiskinan subjektif yang terakhir adalah relasional, dimana aspek ini memiliki dua indikator perilaku yang perlu diuji, yakni: (2) minimnya jumlah saudara yang dimiliki, dan (2) merasa miskin karena sulit menjalin relasi sosial dengan orang-orang terdekat.

Mengingat bahwa konsep dan aspek-aspek dari kemiskinan subjektif ini merupakan hasil penelitian eksplorasi, maka analisis faktor yang tepat untuk uji validitas konstruk dalam skala ini adalah dengan teknik Exploratory Factor Analysis (EFA). EFA memiliki dua tujuan utama, yakni mengurangi jumlah item dalam skala sehingga item yang tersisa memaksimalkan varians dan reliabilitas alat ukur, serta mengidentifikasi dimensi-dimensi potensial yang menjelaskan konstruk (Netemeyer et al, 2003). EFA juga memungkinkan untuk mengidentifikasi ambiguitas butir-butir karena memiliki muatan faktor yang sama-sama kuat pada lebih dari satu faktor penyusun. Untuk meminimalisasi peluang tumpang tindih antara indikator satu dengan lainnya pada setiap aspek kemiskinan subjektif, maka pengujian konstruk kemiskinan subjektifdengan EFA pada Studi 2 ini akan diterapkan satu persatu pada setiap aspeknya.

\section{Studi 2}

\section{Metode Penelitian}

Seperti halnya pada Studi 1, maka sampel dalam penelitian Studi 2 juga dipilih dengan cara incidental sampling (Kumar, 1999). Jumlah sampel Studi 2 sebanyak 135 partisipan $(M=19,87, S D=1,67)$. Pengumpulan data dengan Skala Kemiskinan Subjektif yang disusun peneliti berdasarkan aspekaspek yang ditemukan dalam Studi 1 sebelumnya. Tabel 2 menguraikan definisi konstruk pada tiap apek dan indikator perilaku masing-masing, serta kode item yang diuji cobakan.

Seperti yang telah diungkapkan sebelumnya, bahwa Studi 2 ini bertujuan untuk mengembangkan satu rancangan pengukuran kemiskinan subjektif yang didasarkan pada aspek-aspek kemiskinan subjektif yang telah ditemukan pada studi eksploratif sebelumnya (Studi 1), maka diperlukan pengujian pula terhadap indikator-indikator perilaku pada tiap aspeknya dengan cara menerapkan teknik analisis faktor EFA pada setiap aspek secara terpisah. Hal ini dilakukan untuk meminimalisasi peluang tumpang tindih antara indikator satu dengan lainnya pada setiap aspeknya jika dilakukan dalam satu kali analisis faktor yang melibatkan semua indikator dari seluruh aspek kemiskinan subjektif.

\section{Hasil Penelitian}

Sebagai langkah awal dari pengujian validitas alat ukur ini adalah melakukan uji keterbacaan dan uji validitas isi dengan cara menggunakan penilaian 
Tabel 2. Aspek, definisikonstruk, dan indikator perilaku kemiskinan subjektif

\begin{tabular}{|c|c|c|c|c|}
\hline \multirow{2}{*}{ Aspek } & \multirow{2}{*}{ Konstruk } & \multirow{2}{*}{ Indikator perilaku } & \multicolumn{2}{|c|}{ Item } \\
\hline & & & Kode & Jml \\
\hline \multirow{11}{*}{ Material } & \multirow{11}{*}{$\begin{array}{l}\text { Keterbatasan dalam hal materi } \\
\text { dan penghasilan, baik yang } \\
\text { berupa uang, rumah, } \\
\text { kendaraan, jaminan asuransi } \\
\text { dan/atau kebutuhan lainnya. }\end{array}$} & & MAT1 & \\
\hline & & Merasa jumlah uang yang dimiliki & MAT2 & 3 \\
\hline & & & MAT3 & \\
\hline & & Belum memiliki rumah sendiri, & MAT4 & \\
\hline & & barang elektronik, dan kendaraan & MAT5 & 3 \\
\hline & & pribadi. & MAT6 & \\
\hline & & & MAT7 & \\
\hline & & Belum memiliki penghasilan sendiri. & MAT8 & 3 \\
\hline & & & $\begin{array}{c}\text { MAT9 } \\
\text { MAT10 }\end{array}$ & \\
\hline & & Tidak memiliki jaminan asuransi & MAT11 & 3 \\
\hline & & & MAT12 & \\
\hline \multirow{9}{*}{ Spiritual } & \multirow{9}{*}{$\begin{array}{l}\text { Merasa kurang menguasai } \\
\text { ilmu agama, kurang dekat } \\
\text { dengan Tuhan, dan kurang } \\
\text { bermanfaat bagi orang lain. }\end{array}$} & & SPI1 & \\
\hline & & Merasa kurang mengerti dan & SPI2 & 3 \\
\hline & & & SPI3 & \\
\hline & & & SPI4 & \\
\hline & & Merasa jauh dari Tuhan. & SPI5 & 3 \\
\hline & & & SPI6 & \\
\hline & & & SPI7 & \\
\hline & & Belum sepenuhnya bermanfaat untuk & SPI8 & 3 \\
\hline & & & SPI9 & \\
\hline \multirow{6}{*}{ Intelektual } & \multirow{6}{*}{$\begin{array}{l}\text { Kekurangan dari segi ilmu } \\
\text { pengetahuan/wawasan, } \\
\text { pengalaman dan prestasi. }\end{array}$} & & INT1 & \\
\hline & & 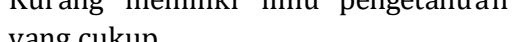 & INT2 & 3 \\
\hline & & & INT3 & \\
\hline & & Merasa kurano nenoalaman & INT 4 & \\
\hline & & 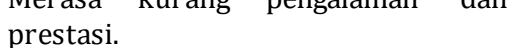 & INT5 & 3 \\
\hline & & & INT 6 & \\
\hline \multirow{6}{*}{ Emosional } & \multirow{6}{*}{$\begin{array}{l}\text { Kurang kasih sayang dan } \\
\text { mudah merasa iri saat melihat } \\
\text { keadaan orang lain yang } \\
\text { menurutnya lebih kaya dan } \\
\text { beruntung. }\end{array}$} & & EM01 & \\
\hline & & kur ang Kasm say ang dar & EMO2 & 3 \\
\hline & & & EMO3 & \\
\hline & & & EMO4 & \\
\hline & & Merasa iri dengan orang lain yang & EM05 & 3 \\
\hline & & & EM06 & \\
\hline \multirow{6}{*}{ Relasional } & \multirow{6}{*}{$\begin{array}{l}\text { Minimnya jumlah saudara } \\
\text { yang dimiliki dan merasa } \\
\text { kurang berhasil dalam } \\
\text { menjalin relasi interpersonal } \\
\text { dengan orang sekitarnya. }\end{array}$} & jumlah saudara vano & REL1 & \\
\hline & & dimiliki & REL2 & 3 \\
\hline & & & REL3 & \\
\hline & & Sulit menialin relasi sosial denoan & REL4 & \\
\hline & & orang-orang terdekt & REL5 & 3 \\
\hline & & & REL6 & \\
\hline \multicolumn{4}{|c|}{ Jumlah } & 39 \\
\hline
\end{tabular}

dari teman sejawat (dosen) dan calon responden (mahasiswa) yang merupakan representasi dari Subject Matter Experts (SME). Validitas ini dengan mencari Content Validity Ratio (CVR), yaitu metode penelitian untuk mengukur persetujuan atau tingkat kesesuaian antar penilai (Lawshe, 1975). Sebanyak 20 Subject Matter Experts (SME) diminta untuk menilai "esensial" setiap item yang telah disusun peneliti, apakah sesuai dengan operasionalisasi aspek-aspek pengukuran atau tidak. Item dinilai esensial jika merepresentasikan dengan baik tujuan pengukuran. Skor CVR diperoleh dengan mengacu pada rumus penghitungan CVR dari Lawshe (1975), yakni: CVR=(2ne/n)-1 (Azwar, 2012). Dengan penjelasan bahwa ne adalah banyaknya SME yang menilai item tersebut esensial, sedangkan $\mathrm{n}$ adalah jumlah keseluruhan SME. Skor CVR berkisar antara 1 hingga 1, semakin tinggi (mendekati angka 1), semakin tinggi validitas isi dari item tersebut atau mewakili domain yang diukur. Item dengan nilai skor CVR $=0$ juga dinilai valid karena $50 \%$ dari SME menyatakan item esensial. Untuk item yang kurang mewakili domain dapat ditinggalkan atau dilakukan perbaikan, lalu dimintakan penilaian kembali sesuai dengan blue-printinstrumen.

Uji relevansi item dengan indikator dari segi kebahasaan, dilakukan uji coba terbatas ( $\mathrm{N}=10$ orang mahasiswa). Uji validitas isi melalui expert/proffesional judgement (Azwar, 2012) atau melibatkan panelis untuk diukur esensi item dengan penghitungan rumus Content Validity Ratio (CVR) dari Lawshe 
Tabel 3. Komponen rotasi, komunalitas, dan varians yang dijelaskan tiap komponen pada aspek material

\begin{tabular}{|c|c|c|c|c|}
\hline \multirow{2}{*}{ Item Aspek Material (MAT) } & \multicolumn{3}{|c|}{ Komponen } & \multirow{2}{*}{ Komunalitas } \\
\hline & 1 & 2 & 3 & \\
\hline Material1 (MAT1) & 0,729 & & & 0,546 \\
\hline Material2 (MAT2) & 0,792 & & & 0,642 \\
\hline Material3 (МАT3) & 0,690 & & & 0,483 \\
\hline Material5 (MAT5) & & 0,799 & & 0,643 \\
\hline Material6 (MAT6) & & & 0,932 & 0,871 \\
\hline Material7 (MAT7) & & 0,721 & & 0,570 \\
\hline Material9 (MAT9) & & 0,511 & & 0,332 \\
\hline Material10 (MAT10) & 0,510 & & & 0,356 \\
\hline Varians yang dijelaskan & 1,938 & 1,442 & 1,063 & \\
\hline Varians dalam \% & 24,228 & 18,019 & 13,289 & \\
\hline Komulatif varians dalam \% & 24,228 & 42,247 & 54,536 & \\
\hline
\end{tabular}

grup, yakni mahasiswa Psikologi yang sudah lulus mata kuliah metodologi penelitian kuantitatif, metodologi penelitian kualitatif, dan konstruksi tes/penyusunan skala psikologi.

Penentuan validitas isi jika menggunakan CVI Aiken, mengacu pada Tabel Right-tail probabilities (p) for selected values of the Validity Coefficient (V) dari Aiken (1985) untuk jumlah rater sebanyak 20, dengan 3 alternatif jawaban kesesuaian sebanyak tiga, maka nilai $\mathrm{V}$ minimal yang harus dicapai adalah $0,68$ ( $\mathrm{p}=0,37)$. Bila mengacu pada pendapat Lawshe (1975), mengacu pada Tabel Minimun Values of CVR and CVRt, One Tailed Test $(\mathrm{p}=0,05)$, maka nilai minimal yang harus dipenuhi jika melibatkan 20 panelis adalah 0.42 .

Dari 39 item yang direview oleh panelis, diperoleh CVR antara 1,00 (1 item), 0,90 (4 item), 0,80 (6 item), 0,70 (10 item), 0,60 (8 item), 0,50 (5 item), 0,40 (3 item, No.5, 15, 22, 26 ), 0,30 (1 item, No.23), 0,00 (1 item), mengacu pada Tabel (dengan $\mathrm{N}=20$, maka Nilai CVR minimal adalah 0,42). Empat item perlu revisi minor karena dinilai kurang esensial (CVR<0,42), yakni: item nomor 5 yang berisi pernyataan "Rumah yang saya tempati saat ini masih terasa kurang layak untuk dihuni”, nomor 15 "Hanya dengan memiliki wawasan yang luas hal itu dapat mengurangi rasa kurang beruntung yang selama ini masih saya rasakan", item nomor 22 "Setiap saya kurang banyak berdoa, saya merasa makin jauh dari Tuhan dan hal ini membuat saya merasa miskin", item nomor 26 "Saya tidak pernah kesulitan untuk menyumbang saat ada penggalangan dana bagi korban bencana", dan satu item memerlukan revisi mayor karena dinilai sama sekali tidak esensial $(\mathrm{CVR}=0)$, yakni: item nomor 23 "Saya merasa miskin karena amal ibadah saya masih sedikit".

Selanjutnya mengukur daya diskriminasi item untuk mengetahui sejauh mana item-item yang disusun dalam alat ukur tersebut mampu membedakan antara individu atau kelompok individu yang memiliki dengan individu yang tidak memiliki atribut yang diukur. Indeks daya diskriminasi item ini merupakan indikator keselarasan atau konsistensi antara fungsi item dengan fungsi skala secara keseluruhan atau konsistensi item total (Azwar, 2012). Lebih lanjut dikatakan Azwar, pengujian daya diskriminasi item dilakukan dengan cara menghitung koefisien korelasi antara distribusi skor item dengan distribusi skor skala itu sendiri. Komputasi ini menghasilkan koefisien korelasi item-total $\left(r_{\mathrm{ix}}\right)$, item dengan koefisien sama dengan atau lebih besar dari 0,30 dianggap memuaskan. Pada sisi lain, ditekankan oleh Azwar (2012) bahwa parameter $\left(\mathrm{r}_{\mathrm{ix}}\right)$ hendaknya tidak dijadikan patokan tunggal. Diperlukan pertimbangan lain yang mencakup komposisi aspekaspek atau komponen-komponen yang dicakup dalam domain ukuryang harus diungkapkan oleh alat ukur itu sendiri. Oleh karena itu, diperlukan pengujian validitas konstruk selanjutnya melalui analisis faktor. Berikut ini hasil analisis dengan EFA pada tiap aspek kemiskinan subjektif.

\section{Aspek Material Kemiskinan Subjektif dan Indikatornya}

Hasil analisis faktor eksploratori pada aspek material dengan 12 item menunjukkan KeiserMeyers-Oklin (KMO $=0,670, \mathrm{p}<0,01)$ dan nilai Barlett Test of Sphericity $=248,862 \quad(\mathrm{p}<0,01)$, sehingga memenuhi kriteria untuk dilakukan analisis faktor. Dari Tabel AIC tidak ditemukan harga MSA di bawah 0,50, sehingga semua item diikutsertakan dalam analisis. Dari total variance explained menunjukkan nilai eigen values yang di atas 1 sebanyak empat faktor/komponen dengan kemampuan menjelaskan konstruk secara komulatif sebesar $56,77 \%$. Temuan ini sekilas tampak mendukung hasil studi eksplorasi dimana aspek material tersusun dari empat indikator perilaku dan muatan faktor tiap item $>0.30$. Namun terdapat empat item yang memiliki muatan faktor pada dua komponen sehingga dikeluarkan secara bertahap, yakni item MAT4, MAT8, MAT11, dan MAT12. Dan hasil akhir dengan delapan item dianalisis lagi dan diperoleh $\mathrm{KMO}=0,635(\mathrm{p}<0,01)$, Barlett Test $=94,460(\mathrm{p}<0,01)$ 
Tabel 4. Komponen rotasi, komunalitas, dan varians yang dijelaskan tiap komponen pada aspek spiritual

\begin{tabular}{lrcrc}
\hline \multirow{2}{*}{ Item Aspek Spiritual (SPI) } & \multicolumn{3}{c}{ Komponen } & \multirow{2}{*}{ Komunalitas } \\
\cline { 2 - 4 } & 1 & 2 & 3 & \\
\hline Spiritual1 (SPI1) & & 0,528 & & 0,925 \\
Spiritual3 (SPI3) & 0,808 & & & 0,330 \\
Spiritual4 (SPI4) & & 0,668 & & 0,731 \\
Spiritual6 (SPI6) & 0,838 & & & 0,509 \\
Spiritual8 (SPI8) & & 0,697 & & 0,762 \\
Spiritual9 (SPI9) & 1,380 & 1,218 & 1,076 \\
\hline Varians yang dijelaskan & 23,003 & 20,306 & 17,927 & \\
Varians dalam \% & 23,003 & 43,309 & 61,236 & \\
Komulatif varians dalam \% & & &
\end{tabular}

Tabel 5. Komponen rotasi, komunalitas, dan varians yang dijelaskan tiap komponen pada aspek intelektual

\begin{tabular}{lccc}
\hline \multirow{2}{*}{ Item Aspek Intelektual (INT) } & \multicolumn{2}{c}{ Komponen } & \multirow{2}{*}{ Komunalitas } \\
\cline { 2 - 3 } & 1 & 2 & \\
\hline Intelektual1 (INT1) & 0,784 & & 0,650 \\
Intelektual2 (INT2) & 0,769 & & 0,640 \\
Intelektual4 (INT4) & & 0,737 & 0,591 \\
Intelektual5 (INT5) & & 0,760 & 0,612 \\
\hline Varians yang dijelaskan & 1,290 & 1,203 & \\
Varians dal am \% & 32,245 & 30,087 & \\
Komulatif varians dalam \% & 32,245 & 62,333 & \\
\hline
\end{tabular}

dan MSA $>0,50$. Dengan demikian telah memenuhi syarat untuk dilakukan EFA. Hasil ekstraksi faktor Principal Component Analysis setelah dilakukan rotasi faktor dapat dilihat dalam Tabel 3, dengan metode varimax untuk memaksimalkan jumlah varians dalam muatan faktor diperoleh total variance explained menunjukkan nilai eigen values yang di atas satu sebanyak tiga komponen dengan kemampuan menjelaskan konstruk secara kumulatif sebesar $54,54 \%$.

Dari hasil analisis tersebut tampak bahwa aspek material dalam kemiskinan subjektif yang semula dari hasil eksploratif diduga memiliki empat komponen yang menjadi indikator perilaku terbukti hanya memiliki tiga indikator perilaku saja, yakni: (1) memiliki keterbatasan uang untuk memenuhi kebutuhan dasar, (2) merasa tidak puas dari segi penghasilan dan jaminan kesehatan, (3) merasa tidak sejahtera karena masih bergantung pada orangtua.

\section{Aspek Spiritual Kemiskinan Subjektif dan} Indikatornya

Hasil analisis faktor eksploratori pada aspek spiritual dengan sembilan item menunjukkan KMO= 0,525 ( $\mathrm{p}<0,01)$, Barlett Test $=108,990(\mathrm{p}<0,01)$, MSA $>0,50$ dan total variance explained menunjukkan nilai eigen values yang di atas 1 sebanyak lima komponen dengan kemampuan menjelaskan konstruk secara kumulatif sebesar 73,74\%. Terdapat tiga item yang tidak diikutsertakan karena memiliki muatan faktor yang berimbang pada dua komponen, yakni item SPI2, SPI5, dan SPI7. Analisis faktor selanjutnya dengan enam item menunjukkan $\mathrm{KMO}=0,465$ $(\mathrm{p}<0,05)$, Barlett Test $=33,246(\mathrm{p}<0,05), \mathrm{MSA}>0,50$. Hasil ekstraksi faktor Principal Component Analysis setelah dilakukan rotasi faktor dapat dilihat dalam Tabel 4, dengan metode varimax tetap menghasilkan tiga komponen dengan kemampuan menjelaskan konstruk secara kumulatif sebesar $61,24 \%$.

Sesuai dengan hasil temuan studi eksploratif bahwa aspek spiritual terbukti memiliki tiga komponen yang dapat menjadi indikator perilaku, yakni: (1) merasa jauh dari Tuhan karena kurang dalam beribadah, (2) merasa belum sepenuhnya bermanfaat untuk orang lain, (3) merasakan kesulitan hidupnya karena keterbatasan ilmu agama.

\section{Aspek Intelektual Kemiskinan Subjektif dan Indikatornya}

Hasil analisis faktor eksploratori pada aspek intelektual dengan enam item menunjukkan $\mathrm{KMO}=$ $0,564(\mathrm{p}<0,05)$, Barlett Test $=35,992(\mathrm{p}<0,05)$, MSA $>0,50$ dan total variance explained menunjukkan nilai eigen values yang di atas 1 sebanyak dua komponen dengan kemampuan menjelaskan konstruk secara kumulatif sebesar $46,17 \%$. Terdapat dua item yang terpaksa tidak digunakan karena memiliki muatan faktor pada dua komponen, yakni item INT3 dan INT6. Analisis faktor dengan empat item terpilih menunjukkan $\mathrm{KMO}=0,500(\mathrm{p}<0,05)$, Barlett Test $=$ $17,383(\mathrm{p}<0,05), M S A>0,50$. Hasil ekstraksi faktor principal component analysis setelah dilakukan rotasi faktor dapat dilihat dalam Tabel 5, dengan metode varimax tetap menghasilkan dua komponen dengan kemampuan menjelaskan konstruk secara kumulatif sebesar $62,33 \%$. Sesuai dengan hasil temuan studi 
Tabel 6. Komponen rotasi, komunalitas, dan varians yang dijelaskan tiap komponen pada aspek emosional

\begin{tabular}{lrrr}
\hline \multirow{2}{*}{ Item Aspek Emosional (EMO) } & \multicolumn{2}{c}{ Komponen } & \multirow{2}{*}{ Komunalitas } \\
\cline { 2 - 3 } & \multicolumn{1}{c}{1} & 2 & 0,817 \\
\hline Emosional1 (EM01) & 0,904 & & 0.804 \\
Emosional3 (EM02) & 0,889 & & 0.717 \\
Emosional5 (EMO5) & & 0,838 & 0.741 \\
Emosional6 (EMO6) & & 0,861 & \\
\hline Varians yang dijelaskan & 1,624 & 1,456 & \\
Varians dalam \% & 40,609 & 36,391 & \\
Komulatif varians dalam \% & 40,609 & 77,000 & \\
\hline
\end{tabular}

Tabel 7. Komponen rotasi, komunalitas, dan varians yang dijelaskan tiap komponen pada aspek relasional

\begin{tabular}{lrrc}
\hline \multirow{2}{*}{ Item Aspek Relasional (REL) } & \multicolumn{2}{c}{ Komponen } & \multirow{2}{*}{ Komunalitas } \\
\cline { 2 - 3 } & \multicolumn{1}{c}{2} & 0,813 & 0,673 \\
Relasional2 (REL2) & & 0,829 & 0,689 \\
Relasional3 (REL3) & & & 0,769 \\
Relasional5 (REL5) & 0,877 & & 0,779 \\
Relasional6 (REL6) & 0,881 & & \\
\hline Varians yang dijelaskan & 1,559 & 1,351 & \\
Varians dalam \% & 38,973 & 33,786 & \\
Komulatif varians dalam \% & 38,973 & 72,759 & \\
\hline
\end{tabular}

eksploratif bahwa aspek intelektual terbukti memiliki dua komponen yang dapat menjadi indikator perilaku, yakni: (1) memiliki keterbatasan dalam pengetahuan dan wawasan, (2) kurangnya pengalaman dan prestasi

\section{Aspek Emosional Kemiskinan Subjektif dan Indikatornya}

Hasil analisis faktor eksploratori pada aspek emosional dengan enam item menunjukkan $\mathrm{KMO}=$ 0,570 ( $\mathrm{p}<0,01)$, Barlett Test $=12,696(\mathrm{p}<0,01)$, MSA $>0,50$ dan total variance explained menunjukkan nilai eigen values yang di atas 1 sebanyak dua komponen dengan kemampuan menjelaskan konstruk secara komulatif sebesar 56,24\%. Tetapi ada satu item yang menduduki dua komponen, yakni item EMO2 dan EMO4. Selanjutnya hasil analisis faktor dengan empat item yakni EM01, EM03, EM05, dan EMO6 menunjukkan KMO = 0,513 ( $<<0,01)$, Barlett Test $=98,138(\mathrm{p}<0,01), \mathrm{MSA}>0,50$. Hasil ekstraksi faktor Principal Component Analysis setelah dilakukan rotasi faktor dapat dilihat dalam Tabel 6, dengan metode varimax tetap menghasilkan dua komponen dengan kemampuan menjelaskan konstruk secara kumulatif sebesar $77 \%$.

Sesuai dengan hasil temuan studi eksploratif bahwa aspek emosional terbukti memiliki dua komponen yang dapat menjadi indikator perilaku, yakni: (1) Kurang kasih sayang dari orang-orang disekitarnya, (2) Merasa iri dengan orang lain yang dinilai lebih kaya dan lebih beruntung.

\section{Aspek Relasional Kemiskinan Subjektif dan Indikatornya}

Hasil analisis faktor eksploratori pada aspek relasional dengan enam item menunjukkan $\mathrm{KMO}=$ 0,610 ( $\mathrm{p}<0,01)$, Barlett Test $=106,723(\mathrm{p}<0,01)$, MSA $>0,50$ dan total variance explained menunjukkan nilai eigen values yang di atas 1 sebanyak dua komponen dengan kemampuan menjelaskan konstruk secara komulatif sebesar 55,69\%. Namun terdapat dua atem yang harus dikeluarkan karena menduduki dua komponen, yakni REL1 dan REL4. Selanjutnya hasil analisis faktor dengan empat item terpilih menunjukkan KMO $=0,501(\mathrm{p}<0,01)$, Barlett Test $=68,186(\mathrm{p}<0,01)$, MSA $>0,50$. Hasil ekstraksi faktor principal component analysis setelah dilakukan rotasi faktor dapat dilihat dalam Tabel 7, dengan metode varimax tetap menghasilkan dua komponen dengan kemampuan menjelaskan konstruk secara kumulatif sebesar $72,76 \%$.

Sesuai dengan hasil temuan studi eksploratif bahwa aspek relasional terbukti memiliki dua komponen yang dapat menjadi indikator perilaku, yakni: (1) minimnya jumlah saudara yang dimiliki, (2) tidak memiliki banyak teman yang baik.

Secara keseluruhan tampak bawa hasil analisis EFA pada tiap aspek yang menjadi konstruk kemiskinan subjektif telah mampu membuktikan adanya indikator-indikator yang kuat dalam menjelaskan kelima aspek kemiskinan subjektif tersebut. Untuk aspek material terbukti memiliki tiga komponen indikator perilaku dengan kemampuan menjelaskan konstruk secara kumulatif sebesar 55,54\%. Sementara aspek spiritual terbukti 
terbukti memiliki tiga komponen sebagai indikator perilaku dengan kemampuan menjelaskan konstruk secara kumulatif sebesar 61,24\%. Aspek intel ektual terbukti memiliki dua komponen sebagai indikator perilaku dengan kemampuan menjelaskan konstruk secara kumulatif sebesar 62,33\%. Aspek emosional terbukti memiliki dua komponen indikator perilaku dengan kemampuan menjelaskan konstruk secara kumulatif sebesar $77 \%$. Terakhir, aspek relasional kemiskinan subjektif terbukti memiliki dua komponen indikator perilaku dengan kemampuan menjelaskan konstruk secara kumulatif sebesar $72,76 \%$.

\section{Diskusi}

Dengan terbuktinya komponen-komponen dari tiap aspek sebagai indikator perilaku kemiskinan subjektif, maka hasil Studi 2 ini menguatkan konsep kemiskinan subjektif sebagai kontruk yang bersifat multidimensional. Kemiskinan tidak hanya dikonstruksi dari keterbatasan aspek material saja, tetapi juga dari aspek spiritual, intelektual, emosional, dan relasional. Untuk semakin memperkuat teori ini, maka perlu dilakukan pengujian lebih lanjut mengenai struktur kelima aspek/faktor tersebut secara keseluruhan dalam menjelaskan kemiskinan subjektif. Dengan demikian kekuatan dari model pengukuran kemiskinan subjektif ini akan lebih teruji, baik dari segi validitas konvergen dan diskrimiannya, serta dari segi keajekan atau reliabilitasnya.

\section{Diskusi Umum}

Penelitian ini menunjukkan bahwa kemiskinan subjektif merupakan konsep yang dapat dikonstruksikan secara multidimensional. Temuan ini sejalan dengan Alkire dan Seth (2009) yang menggunakan sepuluh dimensi (land, housing, food security, sanitation, asset, education, labour, occupation, child status, \& loan) untuk mengidentifikasi orang miskin di India, serta penelitian Alkire dan Santos (2010) yang mengembangkan pengukuran kemiskinan di 104 negara berkembang dengan Indeks Kemiskinan Multidimensi (MPI). Beragamnya aspek penyusun kemiskinan subjektifini juga ditemukan dalam penelitian Beard (1998) yang melakukan studi kasus etnografi dengan melakukan pengamatan selama 22 bulan pada masyarakat di satu lingkungan perkotaan ber-penghasilan rendah (Gondolayu Lor, Yogyakarta). Hasil penelitian menunjukkan bahwa penduduk setempat melakukan konseptualisasi kemiskinan dalam tiga manifestasi kemiskinan yakni: (1) tidak amannya kepemilikan lahan, (2) kurangnya perawatan kesehatan preventif, dan (3) tidak ters edianya informasi dan bahan bacaan. Keterbatasan dalam wujud rasa tidak aman akan kepemilikan lahan dan kurangnya perawatan kesehatan preventif identik dengan aspek material dari kemiskinan subjektif yang ditemukan dalam studi pada mahasiswa ini. Sementara tidak tersedianya informasi dan bahan bacaan merupakan bagian dari aspek intelektual dalam kemiskinan subjektif pada mahasiswa. Aspek intelektualitas dalam penelitian Budiantoro dkk (2013) juga disebutkan dalam dimensi pendidikan dari kemiskinan, selain dimensi kesehatan dan stnadar hidup.

Aspek emosional kemiskinan subjektif diindikasikan dari kurangnya kasih sayang orangorang di sekitar dan munculnya rasa iri. Rasa iri sebagai emosi yang cukup nyata dirasakan individu ketika dirinya membandingkan dengan orang lain, sehingga masih merasa miskin. Munculnya emosi iri karena membandingkan keadaan diri dengan orang lain ini sejalan dengan hasil penelitian Faturochman (2005) sebelumnya pada mahasiswa yang menemukan bahwa lebih dari 90 persen dari 110 responden mengaku pernah merasa iri terhadap orang lain. Rasa negatif ini ditunjukkan melalui respon emosional diantaranya berupa iri, yaitu rasa tidak senang karena kesenangan pada orang lain (Faturochman, 2005) atau emosi negatif yang dirasakan individu karena membandingkan diri dengan orang lain (Feather, 2002).

Perasaan ini muncul sebagai respon emosional dalam aspek psikososial. Ini menunjukkan adanya afek negatif sebagai bentuk ketidakpuasan atau kekurangan yang dirasakan seseorang akibat membandingkan dirinya terhadap orang lain yang dirasa lebih memiliki segala sesuatu. Seseorangyang merasakan ketidakpuasan akibat melakukan perbandingan atau disebut sebagai deprivasi relatif, yang menimbulkan rasa negatif (Guimond \& Dambrun, 2002). Lebih lanjut diungkapkan dalam penelitian Guimond dan Dambrun (2002) bahwa ketidaksamaan ekonomi sebagai salah satu latar belakang terjadinya perbandingan sosial. Demikian pula Hasil penelitian Faturochman (2005) menjelaskan bahwa aspek materi yang merujuk pada kondisi ekonomi dan kesejahteraan berupa pendapatan dan kepemilikan menjadi salah satu pemicu munculnya iri. Hal tersebut sejalan dengan temuan studi eksplorasi ini, yaitu bahwa aspek ekonomi berupa keterbatasan finansial, tidak terpenuhinya kebutuhan dasar, dan minimnya materi merupakan aspek terbesar yang merepresentasikan kemiskinan responden.

Sementara pada sisi lain, emosi negatif tersebut akan dapat diminimalisir jika dalam diri individu terdapat rasa syukur. McCullough, Emmons, dan Tsang (2002) mendefinisikan syukur sebagai kecenderungan individu mengenali dengan penuh perasaan terima kasih atas kebaikan orang lain ataupun hasil positif yang diperoleh. Syukur sendiri yang dirasakan responden menggambarkan bentuk penerimaan diri terhadap pemberian rezeki. Pemberian yang dimaksud berasal dari Tuhan, sehingga syukur yang dirasakan responden merupakan faktor internal yang mendorong individu tidak merasa miskin atau menerima kekurangan yang dimiliki. Penelitian Anggarani, Andayani, dan Karyanta (2013) menunjukkan bahwa pelatihan 
syukur terbukti efektif meningkatkan rasa syukur dan kesejahteraan subjektif pada penduduk miskin di Surakarta. Pelatihan ini juga terbukti dapat meningkatkan kesejahteraan subjektif sebagai upaya mengikis mental miskin (Anggarani dan Andayani, 2016) dan berpengaruh pula pada balance affect, dimana rasa syukur akan meningkatkan emosi positif pada diri individu secara lebih permanen dan pada sisi lain akan menurunkan emosi negatifnya (Anggarani dan Andayani, 2017).

Temuan tersebut sejalan dengan penjelasan McCullough dkk. (2002) bahwa sumber kebaikan bisa berasal dari transpersonal. Salah satunya adalah adanya keyakinan bahwa Tuhan YME telah mengatur rezeki setiap orang sesuai dengan kebutuhan masingmasing, sehingga manusia seharusnya tidak perlu khawatir atau takut miskin. Toussaint dan Friedman (2009) menjelaskan bahwa syukur merupakan rasa terima kasih terhadap keadaan dan kondisi hidup, segala yang telah diterima, dialami, sumber spiritual, kelimpahan, pengalaman, kesuksesan, serta anugerah yang akan datang. Penjelasan ini sejalan dengan temuan dalam penelitian ini, tetapi responden yang menjelaskan adanya rasa syukur mendorongnya untuk menerima segala keadaan.

Tidak dimungkiri bahwa spiritualitas dalam kemiskinan acapkali tampak sebagai aspek penyusun kemiskinan subjektif, namun pada sisi lain juga muncul dalam kategorisasi atribusi kausal kemiskinan. Seperti halnya dalam penelitian Noviawati dan Narendri (2017) yang meneliti kemiskinan di Semarang. Mereka menemukan tiga faktor kemiskinan yakni kemalasan, minimnya pekerjaan, dan rendahnya spiritualitas. Aspek spiritual ternyata tidak hanya menonjol dari segi faktor, tetapi juga dalam konsep kemiskinan yang dikemukakan responden. Hasil penelitian ini menunjukkan bahwa perasaan masih kekurangan atau miskin ternyata juga ditandai dengan minimnya amal dan ilmu agama. Temuan ini makin menguatkan bahwa spiritualitas memiliki peran penting pada kehidupan masyarakat Indonesia. Hal ini sejalan dengan survei sebelumnya (Crabtree, 2010) bahwa Indonesia menduduki ranking ke-empat sebagai negara yang memiliki pengaruh agama dalam kehidupan sehari-hari. Pada sisi lain, survei tersebut menunjukkan bahwa keadaan sosioekonomi negara-negara yang menempatkan agama sebagai faktor penting kehidupan rata-rata memiliki pendapatan perkapita rendah. Hal ini sejalan dengan besarnya aspek spiritual dalam konsep kemiskinan setelah aspek ekonomi. Namun demikian masih perlu dilakukan studi lebih lanjut mengenai temuan ini dimana pengamalan agama menjadi aspek pertama dari segi sipritual yang menyebabkan seseorang masih merasa miskin. Hal ini menunjukkan adanya peran perilaku moral yang ikut mempengaruhi penilaian subjek mengenai kemiskinan. Perilaku moral yang termanifestasi dalam penilaian dosa dan kebermanfaatan terhadap orang lain ini apabila dikaji menggunakan penjelasan Tangney, Stuewig, dan Mashek (2007) dapat disebabkan oleh adanya emosi moral yang salah satunya adalah syukur. Penjelasan ini semakin menempatkan spiritualitas tidak hanya sebagai aspek tetapi juga faktor determinan dalam kemiskinan subjektif di Indonesia, khususnya dalam konteks populasi awal penelitian ini.

\section{Kesimpulan}

Dari hasil penelitian ini dapat disimpulkan bahwa kemiskinan subjektif dalam pengalaman mahasiswa merepresentasikan adanya perasaan dan/atau pemiki ran yang menilai dirinya berada dalam keterbatasan material, intelektual, spiritual, relasional, dan emosional. Meskipun hasil penelitian ini telah menemukan dan membuktikan bahwa indikator perilaku pada lima aspek kemiskinan subjektif mampu menjelaskan konstruk dengan baik, tetapi hasil penelitian ini tetap memiliki keterbatasan. Pengujian konstruk kemiskinan subjektif baru dilakukan melalui teknik analisis faktor eksploratori pada tiap aspek penyusun konstruk kemiskinan subjektif. Untuk itu, dalam penelitian selanjutnya perlu dilakukan pengujian konstruk dengan menggunakan analisis faktor konfirmatori guna mengetahui apakah kelima aspek penyusun konstruk kemiskinan subjektif dalam temuan ini bersifat unidimensi atau multidimensi secara statistik. Selain itu juga menguji properti psikometris model pengukuran secara lebih komprehensif, baik dari segi validitas maupun reliabilitasnya. Pengujian analisis faktor konfirmatori ini juga perlu melibatkan sampel penelitian yang semakin luas agar kontribusi teoretis dari penelitian semakin kuat saat dijadikan landasan teori bagi riset-riset selanjutnya.

\section{Daftar Pustaka}

Adi, I. R. (2008). Intervensi komunitas: Pengembangan masyarakat sebagai upaya pemberdayaan masyarakat. Jakarta: Rajawali Pers.

Alkire, S. And Santos, M. E. (2010). Acute multidimensional poverty: A New Index for developing countries'. OPHI Working Paper 38, Oxford University. doi: $10.2139 /$ ssrn. 1815243

Anggarani, F. K., Andayani, T. R. \& Karyanta, N.A. (2013). Peningkatan syukur penduduk miskin melalui intervensi pelatihan syukur di Surakarta. Jurnal Intervensi Psikologi, 5(2), 151-167. 10.20885/intervensipsikologi.vol5.iss2.art1

Anggarani, F. K. \& Andayani, T. R. (2016). Meningkatkan kesejahteraan subyektif melalui rasa syukur sebagai upaya mengikis mental miskin. (Prosiding Meningkatkan Vitalitas Sosial Masyarakat Indonesia Pada Era Liberalisasi Ekonomi dan Politik) 513-530pppp. Surakarta: UNS Press.

Beard, V.A. (1998). The capacity of community-based planning to reduce urban poverty: A case study of Gondolayu Lor In Yogyakarta, Indonesia. (unplublished doctoral disertation The Faculty 
Of Graduate Studies (School Of Community And Regional Planning) The University of British Columbia.

Bergh, A., \& Nilsson, T. (2014). Is Globalization Reducing Absolute Poverty?. World Development, 62(?), 42-61. doi: 10.1016/j.worlddev.2014.04.007

Budiantoro, S., Fanggidae, V., Saputra, W., Maftuchan, A., \& Artha, D.R.P. (2013). Multidimensional Poverty Index (MPI): Konsep dan Pengukurannya di Indonesia. PRAKARSA Economic Policy Working Paper.

Burtless, G., \& Smeeding, T. M. (2001). The Level, Trend, and Composition of Poverty. In S. H. Danziger, \& R. H. Haveman, Understanding Poverty. Cambridge, Massachusetts, and London: Harvard University Press.

Buttler, F. (2013). What determines subjective poverty?: An evaluation of the link between relative incomepoverty measures and subjective economic stress within the EU. Oldenberg. DFG Research Unit Horizontal Europeanization .

Cahyat, A. (2004). Bagaimana kemiskinan diukur? Beberapa model penghitungan kemiskinan di Indonesia. Bogor: Center for International Forestry Research, CIFOR.

Crabtree, S. (2010, Agustus 31). Religiosity Highest in World's Poorest Nations. Diunduh dari Gallup News:

http://news.gallup.com/poll/142727/religios ity-highest-world-poorest-nations.aspx.

Fatony, A. (2011). c. Sosiokonsepsia, 16(2), 123-142.

Faturochman. (2005). Iri dalam Relasi Sosial. Jurnal Psikologi, 33(1), 1-16.

Goedemé, T., \& Rottiers, S. (2011). Poverty in the Enlarged European Union. A Discussion about Definitions and Reference Groups. Sociology Compass, 5(1), 77-91. doi: 10.1111/j.17519020.2010.00350.x

Guimond, S., \& Dambrun, M. (2002). When Prosperity Breeds Intergroup Hostility: The Effects of Relative Deprivation and Relative Gratification on Prejudice. Personality and Social Psychology Bulletin, 28(7), 900-912. doi: $10.1177 / 01467202028007004$

Gwet, K.L. (2014). Handbook of Inter-rater Reliability: The Definitive Guide to Measuring the Extent of Agreement Among Raters (4th Ed). Gaithersburg: Advanced Analytics, LLC.

Haisley, E., Mostafa, R., \& Loewenstein, G. (2008). Subjective Relative Income and Lottery Ticket Purchases. Journal of Behavioral Decision Making, ?(21), 283-295. doi: 10.1002/bdm.588. doi: 10.1002/bdm.588

Hwang, K.K. (2010). Constructive realism and confucian relationalism: an epistimological strategy for the development of indigenous psychology. In Uichol Kim, Kuo-Shu Yang \& Kwang-Kuo Hwang (eds.), Indigenous and Cultural Psychology: Understanding People in Context (pp. 73-108). New York: Springer. doi: 10.1007/0-387-28662-4_4
Kim, U., Yang, K-S., \& Hwang, K.K. (2010). Contributions to indegenous and cultural psychology: Understanding people in context. In Uichol Kim, Kuo-Shu Yang \& Kwang-Kuo Hwang (eds.), Indigenous and Cultural Psychology: Understanding People in Context (pp. 3-26). New York: Springer.

Kumar, R. (1999). Research Methodology : A Step-bystep Guide For Beginners. London: SAGE Publications.

Marks, G. N. (2005). Income Poverty, Subjective Poverty and Financial Stress. Melbourne: Melbourne Institute of Applied Economic and Social Research.

Markum, M. E. (2009). Pengentasan Kemiskinan dan Pendekatan Psikologi Sosial. Psikobuana, 1(1), 1-12.

McCullough, M. E., Emmons, R. A., \& Tsang, J.-A (2002). The Grateful Disposition A Conceptual And Empirical Topography. Journal of Personality and Social Psychology, 82(1), 112127. doi: $10.1037 / 0022-3514.82 .1 .112$

Niemietz, K. (2011). A NewUnderstanding of Poverty: Poverty Measurement and Policy Implications. London: Hobbs the Printers.

Noviawati, P., \& Narendri, N.I. (2017). Nilai-Nilai Kemiskinan Pada Masyarakat Miskin di Daerah Perkotaan dan Pedesaan: Ditinjau Berdasarkan Analisis Atribut Psikologis. Prosiding The $8^{\text {th }}$ Industrial Research Workshop and National Seminar Politeknik Negeri Bandung, 265-273pp-pp.

Sumarto, S. (2013). Mengukur pendapatan dan kemiskinan multidimensi. Jakarta: Smeru Research Institute.

Susilowati, S.H. (2016). Pendekatan skala ekivalensi untuk mengukur kemiskinan. Forum Penelitian Argo Ekonomi,. 28 (2), 91-105. doi: 10.21082/fae.v28n2.2010.91-105

Tangney, J. P., Stuewig, J., \& Mashek, D. J. (2007). Moral Emotions and Moral Behavior. The Annual Review of Psychology, 58(?), 345-372. doi: 10.1146/annurev.psych.56.091103.070145.

Tsui, K. (2002). Multidimensional Poverty Indices. Social Choice and Welfare. 19(1), 69-93. doi: 10.1007/s355-002-8326-3

Van Praag. B.M.S. \& Ferrer-i-Carbonell, A. (2005). A Multi-dimensional Approach to Subjective Poverty. Working Paper for the conference: The Measurement of Multidimensional Poverty. Theory and Evidence of the International Poverty Centre.Brasilia.1-36. URL: http://www.iae.csic.es/investigators Material / a71312152653archivoPdf62069.pdf 